\title{
To replikker til Mette Skak
}

FRA: John T. Lauridsen, forskningschef på Det Kgl. Bibliotek; Rasmus Mariager, post.doc. på Saxo-Instituttet, Kbh. Univ.; Thorsten Borring Olesen professor på Institut for Kultur og Samfund, Aarhus Univ.; Poul Villaume, professor på Saxo-Instituttet, Kbh. Univ.

\section{Udenrigs 2/2011 anmelder Mette}

Skak over seks sider GADs nye leksikon Den Kolde Krig og Danmark, som undertegnede har redigeret og bidraget til. Mette Skaks ene hovedanke mod leksikonet er, at de fleste af de ca. 70 bidragyderne anlægger en 'skævvredet' og 'tendentiøs', såkaldt postrevisionistisk tolkningsramme for den kolde krig og Danmarks rolle i den. I den forstand lægger Skak sig i slipstrømmen på den velorkestrerede bredside mod leksikonet, som en lille kreds af erklærede kultur- eller værdikæmpere med en nytraditionalistisk tolkning af den kolde krigs historie fremførte i en stribe indlæg i dele af dagspressen i forbindelse med udgivelsen af værket.

Traditionalismen har rødder i 1950'ernes isnende ideologiske koldkrigsklima, hvor manikæisk sort-hvid optik dominerede forklaringerne på Øst-Vest-konflikten. For vore dages traditionalister er det derfor stærkt generende, at post-revisionismen internationalt og nationalt for længst er blevet klart dominerende blandt koldkrigshistorikere med adgang til arkiver fra både Vest og Øst. Postrevisionismen nærer aldeles ikke 'ubehag ved at tage klar stilling i spørgsmålet om ansvar i den kolde krig', som Mette Skak hævder. En mindre fordomsfuld og lidt mere omhyggelig læsning af leksikonet end den, Skaks omtale afslører, vil til fulde bekræfte dette (og her tænker vi såmænd slet ikke på den omstændighed, at hun en række steder konsekvent kritiserer Poul Villaume for formuleringer og tolkninger, som Thorsten Borring Olesen lægger navn til i leksikonet).

At beskrive koldkrigen (på vore breddegrader) som et sammenstød mellem 'den retskafne nordiske velfærdsstat og det røde byzantinske nomenklaturavælde', således som Skak gør, vil alle leksikonets bidragydere sikkert godt kunne skrive under på rent normativt - men vel at mærke ikke som en fyldestgørende, forskningsbaseret karakteristik af den magtkamp mellem to atomvåbenbevæbnede supermagtsblokke og dens komplekse politisk-strategiske dynamik, som den kolde krig også var.

Mette Skaks anden hovedanke mod leksikonet er ikke mindre grundlæggende end den første. Hun havde nemlig hellere set et leksikonværk om den kolde krigs historie generelt, og ikke et om den kolde krig i Danmark. Hertil kan vi 
kun svare, at der allerede på engelsk findes diverse samleværker om den internationale kolde krig, senest trebindsværket The Cambridge History of the Cold War (2010). Vi har derfor, også af overkommelighedsgrunde, stillet os selv en anden opgave, nemlig at sammenfatte og formidle den megen nyere danske forskning om Danmarks stilling i den kolde krig. Men selv på den præmis rammer Skaks kritik af leksikonet for 'provinsialisme' ved siden af, for dels indledes det af et længere kapitel (af tre forskellige forfattere) om den globale kolde krigs historie generelt, dels indeholder mange af opslagene faktisk også en (indledende) international kontekstualisering af deres emne.

Dermed er selvfølgelig ikke sagt, at vores leksikon om Danmarks stilling i den kolde krig ikke rummer fejl og mangler. Ej heller kan det 'stå alene', som Skak lidt gammelklogt noterer - hvilket enkeltværk kan det? Men seriøs kritik må være baseret på faglige indsigter og tolkningsmæssige uenigheder baseret herpå, ikke på fordomsprægede fejllæsninger.
FRA: Erik Beukel, seniorforsker ved Dansk Institut for Internationale Studier (DIIS).

I Mette Skaks anmeldelse af 'Den kolde krig og Danmark. Gads leksikon' i Udenrigs, 2/2011 hedder det (s. 113), at NATO-øvelsen Able Archer fra 1983 "fremstilles som om Sovjetunionen for alvor blev opskræmt”.

Det er netop, hvad opslaget ikke gør. I konklusionen hedder det (s. 54): "Blandt de centrale spørgsmål vedrørende Able Archer er, hvorvidt KGB informerede centrale sovjetiske civile og militære beslutningstagere om situationen, og om sovjetiske atomstyrker blev sat i alarmberedskab. Selv om der stadig er uklarheder i forbindelse med begivenhedsforløbet, tyder de foreliggende oplysninger på, at svaret på begge spørgsmål er benægtende, og det indikerer, at krisen omkring selve Able Archer næppe var så farlig, som det kan synes". 